Jurnal Kesehatan Masyarakat

\title{
DETERMINATION OF INTERNAL AND EXTERNAL FACTORS CAUSE PULP TISSUE DISEASES
}

\author{
Ratnawati Hendari ${ }^{\bowtie}$, Irma HY Siregar, Frida Oktaviani \\ Department of Dental Health, Health Polytechnic of Semarang
}

\section{Info Artikel}

Sejarah Artikel:

Diterima 19 November 2014

Disetujui 28 November 2014

Dipublikasikan Januari 2015

Keywords:

Pulp tissue disease;

Internal factors;

External factors.

\begin{abstract}
Factors of the oral cavity (internal) and external factors play an important role in health status of the teeth and mouth. This study was aimed to determine the causes of internal and external diseases of the pulp tissue in the North Karangasem village of Batang regency. This case study was carried out by survey methods. The independent variables were internal factors (plaques, saliva hydration, viscosity, and $\mathrm{pH}$ ) and external factors (behavioral, health services, and genetics). The dependent variable was pulp tissue disease (pulpitis, pulp gangrene, and gangrene radix). Plaque index was measured by PHP-M, while saliva hydration, saliva viscosity, and saliva $\mathrm{pH}$ were measured using GC Dental Saliva Indicator guide. External factors was assessed using a close questionnaire to 99 respondents observed by purposive randomly sampling with slovin formula. The results showed that the pulp tissue disease was caused by internal factor was saliva $\mathrm{pH}$ (44\%) and saliva viscosity (64\%), while external factors were behavioral (64\%) namely incorrect brushing time (54\%), snacking habits of sticky sweet (70\%), and snacking frequency more than 3 times a day (50\%). This study concluded that major cause of pulp tissue disease in North Karangasem village communities of Batang regency was saliva $\mathrm{pH}$ and behavior.
\end{abstract}

\begin{abstract}
Abstrak
Faktor dari dalam rongga mulut (internal) maupun faktor dari luar (eksternal) memegang peranan yang penting dalam mempengaruhi status kesehatan gigi dan mulut. Tujuan penelitian ini adalah untuk mengetahui determinasi faktor internal dan eksternal penyebab penyakit jaringan pulpa pada masyarakat di Kelurahan Karangasem Utara Kabupaten Batang. Jenis penelitian ini adalah survey diskriptif dengan metode yang digunakan adalah case study. Faktor internal yang diamati adalah plak indeks, hidrasi saliva, viskositas saliva dan $\mathrm{pH}$ saliva. Faktor eksternal, meliputi lingkungan, perilaku, pelayanan kesehatan, dan keturunan. Cara mengukur plak indeks menggunakan metode PHP-M . Pengukuran hidrasi saliva, viskositas saliva, dan $\mathrm{pH}$ saliva menggunakan panduan GC Dental Saliva Indicator. Penilaian faktor eksternal menggunakan kuesioner. Pengambilan sampel menggunakan teknik purposive random sampling. Jumlah sampel sebanyak 99 responden usia 15-44 tahun. Hasil penelitian menunjukkan bahwa penyakit jaringan pulpa yang disebabkan oleh faktor internal adalah $\mathrm{pH}$ saliva (44\%) dan viskositas saliva (64\%). Faktor eksternal adalah perilaku (64\%) akibat waktu menyikat gigi yang salah (54\%) dan kebiasaan ngemil dalam memilih jenis makanan manis melekat $(70 \%)$ dan frekuensi ngemil $>3 x$ sehari (50\%). Kesimpulan penelitian ini adalah aktor penyebab utama penyakit jaringan pulpa pada masyarakat di Kelurahan Karangasem Utara kabupaten Batang adalah pH saliva dan perilaku masyarakat.
\end{abstract}

(c) 2015 Universitas Negeri Semarang 


\section{Introductions}

Health development is an integral part of national development in Indonesia, including dental health which should not be abandoned due to the impact of oral health on overall health. In this modern era, several studies conducted in many countries revealed a trend of increasing number of teeth affected by caries (Garcia-Godoy and Hicks, 2008).

Household Health Survey (Survei Ke sehatan Rumah Tangga; SKRT) conducted by the Ministry of Health in 2004 found that the prevalence of dental caries in Indonesia reached 90.05\% (Depkes, 2004). Health Research (Riskesdas) in 2007, also found that the prevalence of caries active in Indonesia's population reached $46.5 \%$, where the prevalence of caries experience reached 72.1\% (Depkes, 2007). Central Java was third ranked of six regions the most active caries in Java, being reached $43.1 \%$ while caries experience was $67.9 \%$.

Caries is a disease of dental hard tissues (enamel and dentine) caused by microbial activity started by demineralization of dental hard tissue and followed by destruction of organic material lead to the pulp disease and resulting in the death of pulp (Pradhan, 2013). If this condition continuously occurred, it may allow for swelling of the root's tip contained bacteria and pus, and will be carried over into other parts of the body through blood vessels.

Caries is caused by some factors such as dietary factors, the host (tooth), bacteria and time (Abou El-Yazeed, 2009). In addition to the above causes, according to Blum in Saputra (2013), the status of health is influenced by behavior, environment, health care, and genetics factors. Of the four factors which interacts each other, the behavior factor plays an important role in influencing the health status of mouth and teeth. Modernization change the lifestyle of the people to be very practical, such as demanding soft meal which easy being eat, chewed and fast. As a result, the use of stomatognatic system components decreased as well as saliva secretion reduced and resulting in the declining of oral hygiene system. The eating habits have evolved and tend to being established from generation to generation through the process of socialization (Kent, 2005).
Previous study on the state of dental and oral diseases in patients come to Batang II Public Health Centers observed the highest rank was the pulp and periapical tissues diseases (63.5\%). From this percentage, $49 \%$ of patients with pulp and tissue diseases found in North Karangasem village and 52\% was in $15-44$ year age group. The high percentage of pulp disease considered that the causes of the pulp disease should be studied. Therefore, the purpose of this study was to determine the cause of internal and external diseases of the pulp tissue in the North Karangasem village of Batang regency.

\section{Methods}

This research was case study which carried out with survey methods combined with cross sectional design. The independent variables in this study was internal factors include plaques, hydration saliva, saliva viscosity , and $\mathrm{pH}$ of saliva, while external factors were behavioral, health services, and genetics. The dependent variable was the pulp tissue disease (pulpitis, pulp gangrene, and gangrene radix).

Plaque index was measured by Personal Hygiene Performance-Modified (PHP-M) method from Marters and Meskins 1972, while saliva hydration, saliva viscosity, and $\mathrm{pH}$ of saliva were measured using GC Dental Saliva Indicator guide.

Assessment of external factors was obtained using a close questionnaire (yes and no answers) where the correct answers were scored 1 and incorrect answers were scored 0 . The questionnaire was tested the validity and reliability prior to using. The results of questionnaire were groupped into good $(>+1 \mathrm{SD})$, moderate (between - 1SD to $+1 \mathrm{SD}$ ), and poor $(<-1 \mathrm{SD})$. The pulp diseases were classified as pulpitis (advanced pulp inflammation, where bacteria have undermined the pulp tissue), gangrene pulp / GP (death of the tooth pulp which the tooth still crowned), gangrene radix / GR (death of the pulp in the root canal, which the tooth usually was uncrowned).

This study was done on the population (9477 people) of North Karangasem village community aged 15-44 years old in Batang regency. The sample was purposive randomly sampled with Slovin formula, and found 99 
respondents. North Karangasem village has 17 hamlets, therefore proportionally was taken 6 respondents for 14 hamlets and 5 respondents for the rest 3 hamlets, respectively.

Data was analysed descriptive quantitatively, and USG (Urgency, Seriousness, Growth) method was used to determine the priority factors causing the pulp tissue disease.

\section{Results and Discussion}

The grouping the causing in pulp tissue disease in North Karangasem village, of Batang regency are presented in Table 1.

Table 1. Age and Pulp Tissue Disease Categorization

\begin{tabular}{|c|c|c|c|c|}
\hline \multirow[b]{2}{*}{$\begin{array}{l}\text { Age } \\
\text { (year) }\end{array}$} & \multicolumn{3}{|c|}{ pulp tissue disease } & \multirow[b]{2}{*}{ Total } \\
\hline & Pulpitis & $\begin{array}{c}\text { Pulp } \\
\text { Gangrene }\end{array}$ & $\begin{array}{l}\text { Radix Gan- } \\
\text { grene }\end{array}$ & \\
\hline $15-17$ & $2(66.6 \%)$ & $1(33.3 \%)$ & 0 & 3 \\
\hline $18-34$ & $16(13.91)$ & $54(46.95)$ & $45(3.13 \%)$ & 115 \\
\hline $35-44$ & $3(3.125 \%)$ & $34(35.41 \%)$ & $59(61.45 \%)$ & 96 \\
\hline Total & 21 & 89 & 104 & 214 \\
\hline
\end{tabular}

The study of internal factors on the pulp tissue disease caused by plaque, saliva hydration, viscosity of saliva and saliva $\mathrm{pH}$ are shown in Table 2.

Table 1 and 2 showed that the pulp tissue disease was getting worse when the age was getting older. The first cause was saliva viscosity which categorised in medium. This medium viscosity of saliva was considered to lead to reduce the self-cleansing ability of saliva on oral cavity. The second cause was the low salivary $\mathrm{pH}$ or in acidic condition that may lead to the tooth demineralization and in turn the pulp tissue disease.

Figure 1 shows that most respondents were categorised in fair, with behavioral and heredity factors were lower than the environmental and health care factors.

The priority problem of cause pulp tissue disease was determined using the USG method, and it can be sorted as follows. a) Behavior. This included false teeth brushing time and snacking habits, b) Salivary $\mathrm{pH}$. The results showed $44 \%$ of salivary $\mathrm{pH}$ was acid, c) Salivary viscosity. $64 \%$ of respondents has a
Table 2. Results of Plaque Index, Saliva Hydration, Saliva Viscosity and Saliva pH Examinations

\begin{tabular}{|c|c|c|c|}
\hline Score & Criteria & Total & Percentage \\
\hline \multicolumn{4}{|l|}{ plaque index } \\
\hline 0 & Very Good & 1 & 1 \\
\hline $0.1-1.7$ & Good & 51 & 52 \\
\hline $1.8-3.4$ & Moderate & 41 & 41 \\
\hline $3.5-5.0$ & Poor & 6 & 6 \\
\hline Total & & 99 & 100 \\
\hline \multicolumn{4}{|l|}{ saliva hydration } \\
\hline$<30$ second & High & 27 & 27 \\
\hline $30-60$ second & Normal & 61 & 62 \\
\hline$>60$ second & Low & 11 & 11 \\
\hline Total & & 99 & 100 \\
\hline \multicolumn{4}{|l|}{ saliva viscosity } \\
\hline $\begin{array}{l}\text { Clear, aqueous, } \\
\text { non-foaming }\end{array}$ & Normal & 21 & 21 \\
\hline white, foamy & Moderate & 63 & 64 \\
\hline $\begin{array}{l}\text { sticky, white, } \\
\text { and foamy }\end{array}$ & Poor & 15 & 15 \\
\hline Total & & 99 & 100 \\
\hline \multicolumn{4}{|l|}{$\mathrm{pH}$ of saliva } \\
\hline $5.0-5.8$ & Acid & 44 & 44 \\
\hline $6.0-6.6$ & Neutral & 35 & 36 \\
\hline $6.8-7.8$ & Alkalic & 20 & 20 \\
\hline Total & & 99 & 100 \\
\hline
\end{tabular}

Source : primary data

problem on viscosity, d) Environment, including a education level, no permanent jobs, insufficient income, inavailable dental clinic around work place, well-water for daily consuming, e) Health care, including lack of dental health education, h) Hydration of saliva, plaque index, and genetics.

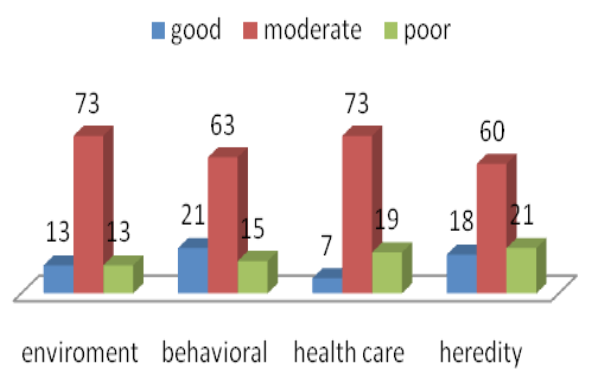

Figure 1. External Factors that Related with Pulp Tissue Dissease

Source : primary data 


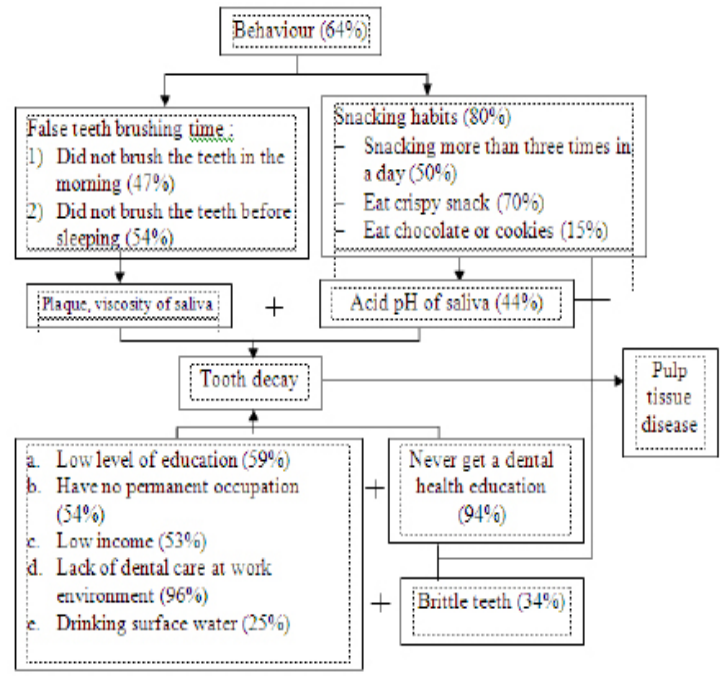

Figure 2. Factors Caused Pulp Tissue Dissease

Figure 2 shows that people's behavior in maintaining oral hygiene was poor. They tend to brush the teeth not in the time after breakfast, or at night before bed. Thus, this resulting in a residual food in the mouth which unfortunately cannot be cleaned because of low self-cleansing in oral cavity due to the high salivary viscosity, and in turn it lead to become plaque. Plaque contains bacteria. Bacteria will convert carbohydrates into glucose and acid through the fermentation process, so that the teeth is the place for adhesion plaque which causing caries (Pradhan, 2013). Moreover, snacking habits with the sticky kind of food and in often frequencies result in in the changes of salivary $\mathrm{pH}$ in the oral cavity. Salivary $\mathrm{pH}$ is always influenced by some changes on the day and night live rythm, diets, and secretion rate (Dawes, 2003; Anderson, 2007). Diets rich in carbohydrates could increase the production of acid by oral bacteria. The acid will damage tooth enamel through demineralization process and forming dental caries (Stookey, 2008; Jawed, 2012).

Blum theory stated that there were four factors interrellated and influenced each other Bad tooth conditions (tooth cavities) supported by no permanent jobs, less income, and inavailable dental services in the working place, lead the people to take the priority on fulfilling the needs for daily live than to keeping health (Borges, 2012). Low education level make the public into perception that dental observation is not required, and in turn ignoring in oral health. Then, when the fragile condition of tooth was occurred, together with the lack of health workers in providing counseling, this will result in continuous process of dental caries to achieve the pulp tissue. Suhat and Hasanah (2014), said that the low education, work odd jobs, income is not fixed causes people are more concerned with day-to-day needs. Increased knowledge of public can be done by providing counseling by health personnel.

Alternative solutions to that problem is by doing counseling to increase the knowledge about oral health (Borges, 2012). The preventive action could be done by controlling to consume the diet or foods containing fluorine, reducing the consumption of foods that are sweet and sticky, increase the consumption of foods that fibrous and watery. Control the plaque by brushing the teeth at the right time and right way, at least two times a day in the morning after breakfast and the night before sleep.

\section{Conclusion}

The main factors on pulp tissue disease in North Karangasem village, Batang regency was the $\mathrm{pH}$ of saliva and the community behavior.

\section{References}

Abou El-Yazeed, et al. 2009. Relationship between Salivary Composition and Dental Caries Among Egyptian Down Syndrome Children, Aust J Basic Apply Sci, 3: 720-730

Andersson, A, et al. 2007. Effect of a Dental Cream Containing Amorphous Cream Phosphate Complexes on White Spot Lesion Regression Assessed by Laser Fluorescence, Oral Health and Preventive dentistry, 5(3):229-233

Borges, HC., et al. 2012. Socio-behavioral factors influence prevalence and severity of dental caries in children with primary dentition, Brazilian Oral Research, 26(6)

Budiharto. 2010. Pengantar Ilmu Perilaku Kesehatan dan Pendidikan Kesehatan Gigi, EGC : Jakarta.

2007. Riset Kesehatan Dasar (Reskesdas) Nasional 2007

Garcia-Godoy, F., Hicks, MJ. 2008. Maintaining The integrity of The Enamel Surface: The Role of Dental Biofilm, saliva and Preventive Agents in enamel Demineralization and Remineralization, J. Am.Dent Assoc, 138:25S-34S 
Jawed, M., et al. 2012. Protective Effectof Salivary Factors in Dental Caries in Diabetic Patients of Pakistan, J of Diabetes Research, accepted 6 May 2012

Kent, G.G., dan Blinkhorn, A.S. 2005. Pengelolaan Tingkah Laku Pasien Pada Praktek Dokter Gigi, diterjemahkan oleh Budiman, J.A., EGC : Jakarta

Pradhan, D, 2013, Golden Heart of The Nature: Piper betle L. J.of Pharmacognosy and Phyto- chemistry, 1(6):147-167

Saputra, A. D. 2012. Hubungan Tingkat Pengetahuan dengan Perilaku Siswa Kelas Sekolah Dasar. Unnes J. of Public Health, 1 (1): 1-7

Suhat dan Hasanah, R. 2014. Faktor-Faktor yang Berhubungan dengan Keaktifan Kader dalam Kegiatan Posyandu (Studi di Puskesmas PalasariKabupaten Subang). J. Kesehatan Masyarakat, 10(1):73-79 